\title{
Correlation, Regression Coefficient Analysis among Yield and Yield Traits in Wheat (Triticum aestivum)
}

\author{
Arjun Lal Prajapat ${ }^{1 *}$, Rani Saxena ${ }^{1}$, P. K. Kaswan ${ }^{2}$, Vinod Kumar Kudi ${ }^{3}$, \\ Ramdhan $\mathrm{Jat}^{4}$ and Manish Kumar
}

${ }^{1}$ Division of Agronomy, Rajasthan Agricultural Research Institute, SKNAU, Durgapura, Jobner, India

${ }^{2}$ Department of Horticulture, College of Agriculture, Swami Keshwanand Rajasthan Agricultural University, Bikaner, India

${ }^{3}$ Department of Agronomy, Institute of Agriculture sciences, BHU, Varanasi, Utter Pradesh, India

${ }^{4}$ Department of Agronomy, C.P. College of Agriculture, Sardarkrushinagar Dantiwada Agricultural University, Sardarkrushinagar, Gujarat, India ${ }^{5}$ Sri Karan Narendra Agriculture University, Jobner, India

*Corresponding author

\section{A B S T R A C T}

\section{Keywords}

Yield Traits in Wheat,

Triticum aestivum

\section{Article Info}

Accepted:

04 October 2020

Available Online:

10 November 2020
A field experiment was conducted under loamy sand soil during two consecutive Rabi seasons of 2016-17 and 2017-18 at Research Farm, Rajasthan Agricultural Research Institute, Sri Karan Narendra Agriculture University, Durgapura, Jobner. The results revealed that Yield components (Plant height, dry matter, number of total and fertile tillers per metre row length, number of grains per spike, Spike length, Spikelets per spike, Number of spikes per metre square, 1000 grain weight and Leaf area index) were studied in two seasons in order to predict their effect and to determine their effects on grain yield in order to define selection criteria for grain yield. Results revealed all studied traits were positively correlated with grain yield, and had a significant regression with grain yield and these traits.

\section{Introduction}

Wheat [Triticum aestivum (L.) emend. Fiori \& Paol)] is grown all over the world for its wider adaptability and high nutritive value than any other food crop. Currently it is grown on an area of about 224.82 million hectares and production of about 732.98 million tonnes with productivity of 3.26 tonnes per hectare (Anonymous, 2015a). Since 1960, world production of wheat and other grain crops has tripled and is expected to grow further through the middle of the $21^{\text {st }}$ century. It is occupying 17 per cent of crop acreage worldwide, feeding about 40 per cent of the world population and good supplement 
for nutritional requirement of human body as it contains 12.60 per cent protein and 78.10 per cent carbohydrate (Kumar et. al., 2011). Global demand of wheat is increasing due to the unique viscoelastic and adhesive properties of gluten proteins, which facilitate the production of processed foods, whose consumption is increasing as a result of the worldwide industrialization process and the westernization of the diet. India has the largest area under wheat cultivation (30.4 million hectares), but ranks second in production (99.70 million tonnes) after China with the average productivity of $3279 \mathrm{~kg} \mathrm{ha}^{-1}$ (ICAR-IIWBR, 2018). In Rajasthan, the crop occupies an area of 3.0 million hectares and production of 11.2 million tonnes with an average productivity of $3674 \mathrm{~kg} \mathrm{ha}{ }^{-1}$ (Anonymous, 2018).

Yield of crop is a complex function of metabolic and bio-chemical processes taking place in a plant system which may be modified by the environment and the suitable cultural practices adopted in the cultivation of the crop. Generally, economic yield depends on the fruiting organs produced by plant. In wheat, yield depends mostly on yield attributes viz., effective tillers, number of grains spike ${ }^{-1}$, spike length, number of spikelets spike $^{-1}$, number of spikes per unit area and test weight. In present study, effective tillers, number of grains spike $^{-1}$, spike length, number of spikelets spike $^{-1}$, number of spikes per unit area and test weight was taken as components related with the grain yield of wheat. Several researchers have reported their findings regarding the correlation studies. Virk and Anand (1970) showed that in wheat grain yield was positively correlated with 1000 grain weight. Sandhu and Mangat (1985), Eunus et al., (1986), Chowdhry et al., (1991), Belay et al., (1993) and Aycecik and Yildirim (2006) reported positive correlation of grain yield with number of grains per spike, plant height and 1000 grain weight. Gupta et al., (1999) and Chowdhry et al., (2000) also conducted such studies and concluded that yield components like tillers per plant, grains per spike and 1000 grain weight are main contributors to grain yield in wheat.

The present study was conducted to estimate the correlation between studied traits, and to predict their effect on grain yield through regression analysis, and to determine their direct and indirect effects on grain yield in order to define selection criteria for grain yield.

\section{Materials and Methods}

The field experiment was conducted during Rabi season 2016 and 2017 at Research farm, Rajasthan Agricultural Research Institute, Sri Karan Narendra Agriculture University, Durgapura, Jobner, Rajasthan ( $75^{\circ} 47^{\prime}$ East longitudes, $26^{\circ} 51^{\prime}$ ' North latitude and at altitude of $390 \mathrm{~m}$ above mean sea level). The soil of experimental field was loamy sand in texture, slightly alkaline in reaction containing $0.25 \%$ organic $\mathrm{C}$, with $p \mathrm{H} 8.2$, EC $0.15 \mathrm{ds} \mathrm{m}^{-1}$, available nitrogen $136.5 \mathrm{~kg} \mathrm{ha}^{-1}$, phosphorous $33.30 \mathrm{~kg} \mathrm{ha}^{-1}$ and potassium $195.45 \mathrm{~kg} \mathrm{ha}^{-1}$. The meteorological data was recorded daily from sowing to harvest from meteorological observatory situated near the experimental farm.

The experimental site characterized by aridity of the atmosphere and extremity of temperature both in summer $\left(45.5^{\circ} \mathrm{C}\right)$ and winter $\left(4^{\circ} \mathrm{C}\right)$. Under semi-arid climatic conditions, the area receives $500-700 \mathrm{~mm}$ per annum rainfall which is mostly occurring during July to September. Rainfall received during the wheat growing season (Nov. to April) was $22.9 \mathrm{~mm}$. The mean monthly maximum and minimum temperatures during the wheat growing season (Nov. to April) varied from 21.55 to 38.32 and 6.05 to 
$23.25^{\circ} \mathrm{C}$, respectively. The cumulative bright sunshine hours during the growing season varied between 6.70 to $10.05 \mathrm{hrs}$. The experiment was laid out in Split plot design with three replications. Thirty six treatment combinations were investigated. Treatments comprises four irrigation levels: $\mathrm{I}_{1}(0.6 \mathrm{ETc})$, $\mathrm{I}_{2}(0.8 \mathrm{ETc}), \mathrm{I}_{3}(1.0 \mathrm{ETc})$ and $\mathrm{I}_{4}(1.2 \mathrm{ETc})$, three cultivars: $C_{1}$ (Raj-4120), $C_{2}$ (Raj-4079) and $\mathrm{C}_{3}$ (Raj-4238) and three dates of sowing: $\mathrm{D}_{1}$ (15 ${ }^{\text {th }}$ Nov. $), \mathrm{D}_{2}\left(30^{\text {th }}\right.$ Nov. $)$ and $\mathrm{D}_{3}\left(15^{\text {th }}\right.$ Dec.).To describe the relationship between grain yield and the yield attributes, correlation and regression studies were undertaken (Panse and Sukhatne, 1985).

\section{Results and Discussion}

Results of correlation study revealed a strong positive and highly significant correlation between grain yield and Plant height at harvest $(\mathrm{r}=0.964 * *)$ and Dry matter at harvest $\left(\mathrm{g}\right.$ plant $\left.{ }^{-1}\right)$ at harvest $(\mathrm{r}=0.932 * *)$, and Total tillers $\left(\mathrm{r}=0.949^{* *}\right)$, and Spike length $(\mathrm{cm})(\mathrm{r}=0.963 * *)$ and Spikelets per spike $\left(0.969^{* *}\right)$ and Number of spikes per metre square $\left(0.917^{* *}\right)$ and Effective tillers per metre row length $\left(0.940^{* *}\right)$ and Number of grains per spike $\left(0.960^{* *}\right)$ and 1000 grain weight $(\mathrm{g})\left(0.971^{* *}\right)$ and Leaf area index $(0.928 * *)$ (Table 1).

Table.1 Correlation coefficients (r) and regression equations for the relationship between grain yield (Y) $\left(\mathrm{kg} \mathrm{ha}^{-1}\right)$ and growth and yield attributes of crop (X)

\begin{tabular}{|c|c|c|c|c|c|c|c|}
\hline \multirow[t]{2}{*}{ S.No. } & \multirow[t]{2}{*}{ Treatments } & \multicolumn{2}{|r|}{ 2016-17 } & \multicolumn{2}{|c|}{ 2017-18 } & \multicolumn{2}{|c|}{ Pooled } \\
\hline & & $\begin{array}{l}\text { Correlati } \\
\text { on } \\
\text { coefficient } \\
(\mathbf{r})\end{array}$ & $\begin{array}{c}\text { Regression equation } \\
\mathbf{Y}=\mathbf{a}+\mathbf{b}_{\mathbf{y}} \mathbf{x} . \mathbf{X}\end{array}$ & $\begin{array}{l}\text { Correlation } \\
\text { coefficient } \\
(\mathbf{r})\end{array}$ & $\begin{array}{c}\text { Regression } \\
\text { equation } Y=a+b_{y} \\
\text { x. } X\end{array}$ & $\begin{array}{c}\text { Correlation } \\
\text { coefficient (r) }\end{array}$ & $\begin{array}{c}\text { Regression equation } \\
\qquad \mathbf{Y}=\mathbf{a}+\mathbf{b}_{\mathbf{y}} \mathbf{x} . \mathbf{X}\end{array}$ \\
\hline 1. & $\begin{array}{l}\text { Plant height at } \\
\text { harvest }(\mathrm{cm})\end{array}$ & $0.966 * *$ & $\begin{array}{c}Y=-6638.67+126.36 \\
X_{3}\end{array}$ & $0.962^{* *}$ & $\begin{array}{c}\mathrm{Y}=- \\
5676.14+114.74 \mathrm{X}_{3}\end{array}$ & $0.964 * *$ & $\begin{array}{c}Y=-6143.59+120.36 \\
X_{3}\end{array}$ \\
\hline 2. & $\begin{array}{l}\text { Dry matter at } \\
\text { harvest } \\
\left(\mathrm{g} \mathrm{plant}^{-1}\right)\end{array}$ & $0.926^{* *}$ & $\mathrm{Y}=353.45+355.74 \mathrm{X}_{4}$ & $0.936^{* *}$ & $\begin{array}{c}Y=514.90+337.08 \\
X_{4}\end{array}$ & $0.932 * *$ & $\begin{array}{c}Y=429.19+346.69 \\
X_{4}\end{array}$ \\
\hline 3. & Total tillers & $0.943 * *$ & $\begin{array}{c}Y=--4963.36+68.32 \\
X_{5}\end{array}$ & $0.953 * *$ & $\begin{array}{c}Y=-5360.90+70.68 \\
X_{5}\end{array}$ & $0.949 * *$ & $\begin{array}{c}Y=-5166.27+69.53 \\
X_{5}\end{array}$ \\
\hline 4. & $\begin{array}{l}\text { Spike length } \\
\text { (cm) }\end{array}$ & $0.960 * *$ & $\begin{array}{c}Y=-1011.86+370.52 \\
X_{6}\end{array}$ & $0.965^{* *}$ & $\begin{array}{c}Y=1056.06+362.70 \\
X_{6}\end{array}$ & $0.963 * *$ & $\begin{array}{c}Y=1031.73+361.79 \\
X_{6}\end{array}$ \\
\hline 5. & $\begin{array}{l}\text { Spikelets per } \\
\text { spike }\end{array}$ & $0.967 * *$ & $Y=661.32+265.43 X_{7}$ & $0.970 * *$ & $\begin{array}{c}Y=682.92+261.86 \\
X_{7}\end{array}$ & $0.969^{* *}$ & $\begin{array}{c}Y=670.25+263.75 \\
X_{7}\end{array}$ \\
\hline 6. & $\begin{array}{l}\text { Number of } \\
\text { spikes per metre } \\
\text { square }\end{array}$ & $0.925^{* *}$ & $\begin{array}{c}Y=-7693.88+37.09 \\
X_{8}\end{array}$ & $0.967 * *$ & $\begin{array}{c}Y=-7676.61+36.49 \\
X_{8}\end{array}$ & $0.917 * *$ & $\begin{array}{c}Y=-7199.98+36.83 \\
X_{8}\end{array}$ \\
\hline 7. & $\begin{array}{l}\text { Effective tillers } \\
\text { per metre row } \\
\text { length }\end{array}$ & $0.936^{* *}$ & $\mathrm{Y}=218.44+41.54 \mathrm{X}_{9}$ & $0.944 * *$ & $\begin{array}{c}Y=-283.40+45.76 \\
X_{9}\end{array}$ & $0.940 * *$ & $Y=-24.71+43.61 X_{9}$ \\
\hline 8. & $\begin{array}{l}\text { Number of } \\
\text { grains per spike }\end{array}$ & $0.954 * *$ & $\begin{array}{c}Y=657.102+100.03 \\
X_{10}\end{array}$ & $0.964 * *$ & $\begin{array}{c}Y=513.53+102.42 \\
X_{10}\end{array}$ & $0.960 * *$ & $\begin{array}{c}Y=579.99+101.38 \\
X_{10}\end{array}$ \\
\hline 9. & $\begin{array}{l}1000 \text { grain } \\
\text { weight }(\mathrm{g})\end{array}$ & $0.963^{* *}$ & $\begin{array}{c}Y=-11326.5+408.60 \\
X_{11}\end{array}$ & $0.972 * *$ & $\begin{array}{c}\mathrm{Y}=- \\
11214.5+406.76 \mathrm{X}_{11}\end{array}$ & $0.971 * *$ & $\begin{array}{c}Y=-11369.7+410.24 \\
X_{11}\end{array}$ \\
\hline 10 & Leaf area index & $0.900 * *$ & $\begin{array}{c}Y=- \\
2846.03+1711.95 X_{12}\end{array}$ & 0.950 ** & $\begin{array}{c}Y=- \\
5464.16+2260.91 \\
X_{12}\end{array}$ & 0.928 ** & $\begin{array}{c}Y=- \\
4083.18+1974.52 X_{12}\end{array}$ \\
\hline
\end{tabular}


This indicates that growth and yield attributes are directly correlated with the grain yield. Our data are in accordance with earlier results between grain yield and grain number per spike (Rajpoot et al., 2013; Khan and Dar, 2010 and Khokhar et al., 2010).Other studies (Heidari et al., 2005 and Moucheshi et al., 2013) also conducted similar results between grain yield and grain weight per spike. There are reports about the correlation between thousand grain weight and grain yield per plant (Mondal and Khajuria, 2001). Our results also agree with previous findings (Saleh, 2011; Dogan, 2009). The regression coefficients (b) and regression equations were also worked out to quantify the amount of change in grain yield for a unit change in growth and yield attributes of crop and nutrient uptake. The present study results are in agreement with previous studies (Ashraf et al., 2014; Olgun et al., 2011; Efyoni et al., 2005).

\section{References}

Anonymous, (2015a). United States Department of Agriculture, World Agricultural Production, Foreign Agriculture Service, Circular Series, WAP.

Anonymous, (2018). Commissionarate of Agriculture Rajasthan-Jaipur, 2017-18, Government of Rajasthan, www. Rajasthankirshi.org.in.

Ashraf, A., Abd El-Mohsen and Abd ElShafi, M. A. (2014) Regression and path analysis in Egyptian bread wheat. Journal of Agriculture-Food and Applied Sciences, 2(5): 139-148.

Aycecik., M. and Yildirim, T. (2006). Path coefficient analysis of yield and yield components in bread wheat (Triticum aestivum L.) genotypes. Pak. J. Bot., 38(2): 417-424.

Belay, G., Tesemma, T. and Mitiku, D. (1993). Variability and correlation studies in durum wheat in Alem-Tena, Ethiopia. Rachis, 12: 38-41.

Chowdhry, M. A., Alam, K. and Khaliq, I. (1991). Harvest index in bread wheat. Pak. J. Agric. Sci. 28: 207-210.

Chowdhry, M. A., Ali, M., Subhani, G.M. and Khaliq,I. (2000). Path coefficient analysis for water use efficiency, evapotranspiration efficiency, transpiration efficiency and some yield related traits in wheat. Pak. J. Biol. Sci., 3: 313-317.

Dogan R. (2009). Correlation and path coefficient analysis for yield and some yield components of durum wheat (Triticum turgidum var. durum 1.) in West Anatolia Conditions. Pakistan Journal of Botany, 41(3): 1081-1089.

Efyoni, D, and Mahloji, M.(2005) Correlation analysis of some agronomic traits in wheat (Triticum aestivum L.) genotypes under salinity stress. Journal of Seed Plant, 22: 186-199.

Eunus, M., Sarker, D.C., Khan, Z.A. and Sarker, A.U. (1986). Interrelationships among some quantitative characters of wheat. Bangla. J. Agric. Res., 11: 91-94.

Gupta, A.K., Mittal, R.K. and Ziauddin, A. (1999). Association and factor analysis in spring wheat. Ann. Agri. Res., 20: 481-485.

Heidari, B., Saeidi, G., Sayed-Tabatabaei,B. E. and Suenaga, K. (2005) Interrelationships of agronomic characters in a doubled haploid population of wheat. Czech Journal of Genetics and Plant Breeding, 41: 233237.

ICAR-IIWBR, (2018). Director's Report of AICRP on Wheat and Barley Improvement Project 2017-18. Ed: G. P. Singh, ICAR-Indian Institute of Wheat and Barley Research, Karnal, India, 94.

Khan, M. H., and Dar, A. N. (2010) Correlation and path coefficient analysis of some quantitative traits in wheat. African Crop Science Journal, 18(1): 
14-21.

Khokhar, M. I., Hussasn, M., Zulkiffal M., Sabir, W., Mahmood, S., Jamil, M.W., and Anwar, J. (2010) Studies on genetic variability and interrelationship among the different traits in wheat (Triticum aestivum L.), 52(2): 77-84.

Kumar, P., Yadav, R.K., Gollen, B., Kumar, S., Verma, R.K. and Yadav, S. (2011). Nutritional contents and medical properties of wheat. A review Life Sciences and Medicinal Research47: 145-149.

Mondal, S.K. and Khajuria,M.R. (2001) Correlation and path analysis in bread wheat (Triticum aestivum L.) under rainfed condition. Environment and Ecology, 18(2): 405-408.

Moucheshi, A. S., Pessarakli,M. and Heidari, B. (2013) Comparing relationships among yield and its related traits in mycorrhizal and nonmycorrhizal inoculated wheat cultivars under different water regimes using multivariate statistics, International Journal of Agronomy, 1: 1-14.

Olgun, M. and Aygün, C. (2011) Evaluation of yield and yield components by different statistical methods in wheat ( $T$. aestivum L.), Ph.D thesis, Falculty of Agriculture. Department of Field Crops. Eskisehir. Turkey.

Rajpoot, P., Verma, O. and Rajbahadur, P. (2013) Genetic variability, correlation and path coefficient analysis for yield and its contributing traits in wheat [Triticum aestivum (L.)]. International Journal of Science and Research (IJSR), 4(9). 24-29.

Saleh, S. H. (2011) Performance, correlation and path coefficient analysis for grain yield and its related traits in diallel crosses of bread wheat under normal irrigation and drought conditions. World Journal of Agricultural Sciences, 7(3): 270-279.

Sandhu, B.S. and Mangat, N.S. (1985). Interrelationships in some quantitative traits in wheat. Indian J. Agric. Res., 19: 98-102.

Virk, T. S. and Anand, S. C. (1970). Studies on correlation and their implication in wheat (Triticum aestivum L.). Madras Agric. J., 57: 713-717.

\section{How to cite this article:}

Arjun Lal Prajapat, Rani Saxena, P. K. Kaswan, Vinod Kumar Kudi, Ramdhan Jat and Manish Kumar. 2020. Correlation, Regression Coefficient Analysis among Yield and Yield Traits in Wheat (Triticum aestivum). Int.J.Curr.Microbiol.App.Sci. 9(11): 374-378. doi: https://doi.org/10.20546/ijcmas.2020.911.045 